\title{
Determining local wetness conditions within the mined lands using GIS
}

\author{
Oleh Skrypnyk $^{1 \otimes(\bullet)}$, Arkadii Shapar ${ }^{1 \bowtie(1)}$, Oleh Taranenko ${ }^{1 * \otimes(0)}$ \\ ${ }^{1}$ Institute for Nature Management Problems and Ecology of National Academy of Sciences of Ukraine, Dnipro, 49000, Ukraine \\ *Corresponding author: e-mail Taranenko_Oleg@nas.gov.ua, tel. +380567453043
}

\begin{abstract}
Purpose. To provide methodologically determining local wetness conditions within Kryvbas mined lands taking into consideration the surface structure and using geoinformation technologies. Surface structure is the determinative factor effecting local changes in the soil humidification.

Methods. The proposed simplified model of local wetness relies upon correction of potential evaporation value with the allowance for topography as well as consideration of precipitation only as a dampness source. Use of spatial analysis methods in terms of geoinformation systems (GIS) will help identify changes in the surface structure of the mined lands and adequate correction of potential evaporation values.

Findings. Linear dependence between the ratios of potential evaporation within the northern and southern slopes, varying in steepness, to potential evaporation from a horizontal surface (according to the data by E.N. Romanova) and the geometrization slope index for steppe Ukrainian zone has been identified. Moreover, the simplified model of local wetness has helped perform 0.54-1.65 times specification of regional humidity coefficient within the northeast part of technogenic landscape protected area Vizyrka.

Originality. Consideration of structural surface complexity, stipulated by steepness of the slopes and their direction, provides correction of potential evaporation values as well as adequate quantitative determination of local wetness conditions within the mined lands using GIS. It has been defined that the geometrization slope index needs extra correction in terms of the determined potential evaporation values from the slopes having different directions and inclinations.

Practical implications. The proposed approach makes it possible to zone a mine-take territory in terms of potential local surface damping in GIS environment which provides the substantiated selection of prospecting site to introduce plants within the disturbed lands.
\end{abstract}

Keywords: local wetness, geometrization slope index, mined lands, slope steepness, slope direction, GIS

\section{Introduction}

Open-pit mining results in the mechanical plant destruction, transformation of original terrain, and earth and rock moving and storing for an indefinite term. Moreover, the mined lands are the source of technogenic dust pollution [1], [2]. Due to them, global problems of land degradation and biodiversity loss intensify.

Revegetation is the most efficient method to overcome negative effect of the mined lands. Plant rehabilitation is the natural solution to the environmental problems if there are no substantial material expenses to support functioning of natural recovery mechanisms. Other studies show that the increased share of a plant cover results in the decreased degree of erosion by wind and water [3]. Flora is the basic production ecosystem component. It creates environmental conditions to preserve and restore biodiversity. Surface dumping is the key factor limiting vegetation development.

Territory of Kryvyi Rih iron-ore basin (Kryvbas) is in the natural steppe zone characterized by insufficient atmospheric humidification (according to the data by M.M. Ivanov, humidity coefficient is 0.53 ) [4]. Hence, achieving of optimum surface damping is the determinative factor to restore secondary ecosystems within the mined Kryvbas lands. Thus, determination of local wetness conditions within the mined lands is the topical mission of environmental research.

To the first approximation, balance of wetness of slopes, disturbed by mining, is humidification supply and its evaporation loss. The evaporation values are also influenced by thermal surface mode [5] depending among other things upon illumination period of slopes having different directions. In the middle latitudes of the northern hemisphere, the southern slopes get more solar radiation. Consequently, they are more heated than the northern-direction slopes [6]. Alternatively, in the middle latitudes of the southern hemisphere, the northern slopes get more solar radiation than the southern ones [7]. Thus, local evaporation values will also differ for the slopes with different directions. In addition, slope steepness influences the amount of solar radiation obtained by the 
surface [6]. Hence, consideration of the surface structure through such morphometric terrain characteristics as slope steepness and direction will help identify local wetness conditions within the mined lands.

In 1976, L.P. Travleev (under scientific supervision of A.L. Belgard) first proposed a concept to apply a local wetness coefficient (LWC) [8]. In time, the concept evolved [9] and [10]. Other studies also support it [11].

A topographic wetness index (TWI), developed by K.J. Beven \& M.J. Kirkby in 1979, is somewhat different approach to take into consideration local wetness conditions. The index involves only surface runoff conditions through upslope catchment area per unit contour length, and the slope steepness [12]. [13]-[15] papers considered specific features of the TWI calculation. In contrast to TWI, [10] and [11] studies are focused on the correction of surface potential evaporation values.

An issue of the substantiated selection of prospecting sites for plant introduction involving local conditions of surface damping remained unsolved in the context of a problem to reduce dust content of a mining region territory through the goal-oriented restoration of secondary ecosystems within the mined lands.

The research is intended to determine theoretically and practically local wetness conditions taking into consideration the surface structure of the mined lands on the basis of geoinformation analysis data.

The research is aimed at definition of the possibility to apply the abovementioned LWC for Kryvbas to zone territories of the mined lands in terms of the potential surface wetness.

\section{Materials and research methods}

\subsection{Subject of the research}

Kryvyi Rih iron-ore basin is in the central part of Ukraine in the encatchment area of the Inhulets River, and the Saksahan River. Currently, Kryvbas is among the world leaders as for the iron ore extraction. Five ore mining and preparing mills (open pit mining) and about ten underground mines operate in its territory. Almost 27 thousand hectares of land are under mine takes. More than 19 thousand hectares of them are disturbed.

To perform long-term observations about natural changes, taking place at the surface of the mine lands, the northeast part of technogenic landscape protected area Vizyrka has been selected as the studied territory.

The technogenic landscape protected area Vizyrka was brought into being within the disturbed lands of Ingulets Iron Ore Enrichment Works PJSC on the basis of administrative decision of Dnipropetrovsk Regional Council of 28.12.2001 (№502-19/XXIII). The area is 121 hectares. Currently, biodiversity of technogenic landscape protected area Vizyrka is 123 cultures; two of them are from the Red Data Book and one is from the Red List of Dnipropetrovsk Region.

Rock dump (with $600 \mathrm{~m}$ length; $370 \mathrm{~m}$ width; 30-48 m relative height; and up to $56.9^{\circ}$ slope steepness) is in the northeast part of the protected area. Nonavailability of domination of slopes of the certain direction stipulated selection of the area as the studied one. Northern slopes of the rock damp and its southern slopes differ in the degree of the vegetable life amount (Fig. 1). (a)
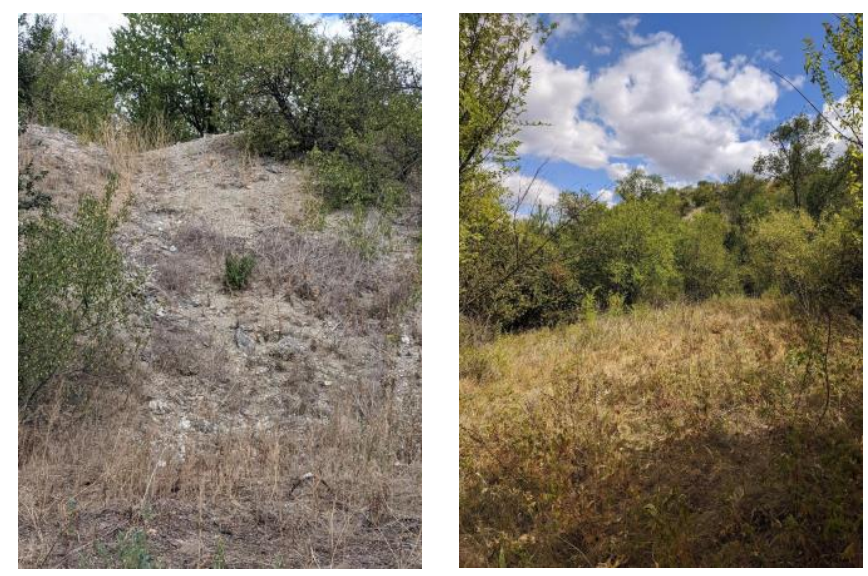

Figure 1. Graphic representation of nonuniformity in the amount of vegetable life as for the rock damp slopes being of different directions: (a) the southern slope; (b) the northwest slope

\subsection{The simplified model of local wetness}

Experimental surface methods, inclusive of thermostatic and weight method as well as electrometric one, are the most popular procedures to identify the soil wetness. However, they cannot provide the soil humidification evaluation between the measuring points. Certain computational methods can solve the problem.

For the first time, such a computational approach was applied to determine atmospheric humidity coefficient (also known as a humidity coefficient by Vysotsky-Ivanov). However, the parameter may be only considered as regional humidity coefficient (HC) since it cannot involve local conditions of surface evaporation:

$$
H C=\frac{P}{E_{0}},
$$

where:

$$
P-\text { is precipitation, } \mathrm{mm} \text {; }
$$

$E_{0}$ - is potential evaporation (i.e. maximum possible evaporation of extra humid surface or water body evaporation), $\mathrm{mm}$.

Regional nature of the index is stipulated by the measured values of weather data at the nearest station of meteorological observations.

Primarily, the concept of local wetness coefficient [8] relied upon the consideration of sources of moisture income to surface soil, namely: atmospheric precipitation, ground water, and runoff (surface runoff, soil runoff etc.) as well as their combination. In terms of the approach, LWC may be represented as:

$$
L W C=\frac{(P+\Delta W+\Delta n)}{E_{0}},
$$

where:

$\Delta W$ - is amount of moisture income at the expense of soil water, $\mathrm{mm}$;

$\Delta n$ - is moisture income amount at the expense of the total runoff, mm. 
Moreover, it has been mentioned that soil humidification also depends upon slope steepness, length, and direction [8]. In this context, the dependence nature was not determined.

In the context of the irrigated lands, LWC development is a local irrigation wetness coefficient involving water requirement as an extra source of moisture income [9].

Potential evaporation value, corrected to the terrain, is further development of LWC [10], [11]. Use of a statistical approach is based upon the application of compensation factors while determining the final value $E_{0}$ [11]. The compensation factors were calculated on the basis of actinometrical observations using slopes of different directions and steepness. However, credibility of extend of the obtained corrections beyond the limits of the experiments remains unascertained.

Use of the calculation approach is based upon geometrization slope index $\left(k_{s}\right)$ for the northern hemisphere involving the slope direction and steepness [10]:

$k_{s}=\frac{\left(\sin \alpha \cdot \cos \left(\beta-180^{\circ}\right)+\cos \alpha\right)}{\cos \alpha}$,

where:

$\beta$ - is surface aspect azimuth, degrees;

$\alpha-$ is slope steepness, degrees.

$k_{s}$ is based upon the irradiance factor of surface by direct solar radiation. A formula, determining direct sun angle in terms of the randomly oriented surface (by G.N. Troshkina) [16] was simplified drastically to use it locally [10], [17].

Geometrization slope index may also be considered as a definite modification of previously known simple solar radiation index (SRI) [18] exclusive of the terrain latitude (which depends upon the local application level) and inclusive of $\cos \alpha$ divider. Right the use of $\cos \alpha$ as a divider provides extra intensification of the correcting factor while varying exposure from $\beta=270^{\circ}$ (the west) down to $\beta=180^{\circ}$ (the south), and from $\beta=90^{\circ}$ (the east) up to $\beta=180^{\circ}$ (the south), and supporting extra reduction of the correcting factor while varying exposure from $\beta=270^{\circ}$ (the west) down to $\beta=0^{\circ}$ (the north), and from $\beta=90^{\circ}$ (the east) down to $\beta=0^{\circ}$ (the north). Owing to $\cos \alpha$ divider, $k_{s}$ is also equal to 1 if $\beta=270^{\circ}$ (the west) and $\beta=90^{\circ}$ (the east). $k_{s}$ is equal to 1 in terms of upland areas if $\alpha=0^{\circ}$ ).

The complexity of determination of adequate values of soil nutrition and the total runoff makes use the simplified model of local wetness (SMLW):

$$
S M L W=\frac{P}{k_{s} \cdot E_{0}} .
$$

The majority of the known methods to calculate potential evaporation rely upon numerous hydrometeorological parameters. Hence, the authors propose to use previously determined empiric dependences (by A.N. Postnikov) between $E_{0}$ and air temperature during ice-free period for an excessively humidified surface [5] or for a water body surface [19].

The temperature characteristics of the analyzed area as well as the information concerning precipitation are identified on the data of the closest weather station.

\subsection{Territory zoning in terms of wetness}

Determination of local wetness conditions within the disturbed areas, using the simplified model (4), makes it possible to zone mine-take territories in terms of a degree of po- tential surface wetness. The simplest zoning alternative is the territory separation into the two classes:

- sites where local wetness is higher than a background value;

- sites where local wetness is lower than a background value.

Regional humidity coefficient may be applied as the background value (1).

Another zoning alternative is the use of the available classification of humidification of geographical zones (by F.N. Mil'kov) with certain modification [20]:

- excessive: $>1$;

- insufficient 1: [0.6-1.0];

- insufficient 2: [0.3-0.6);

- poor 1: [0.13-0.3);

- poor $2:<0.13$.

If territory zoning in terms of the two classes (i.e. higher/lower than a background value) is applied, then it is possible to be limited to calculation of $k_{s}$ index only.

\subsection{Use of GIS analysis data}

Methodological approach has been proposed to identify local wetness conditions at the disturbed lands. The approach relies upon the consideration of a surface structure being a part of mine take under GIS environment through the slope direction and steepness (Fig. 2).

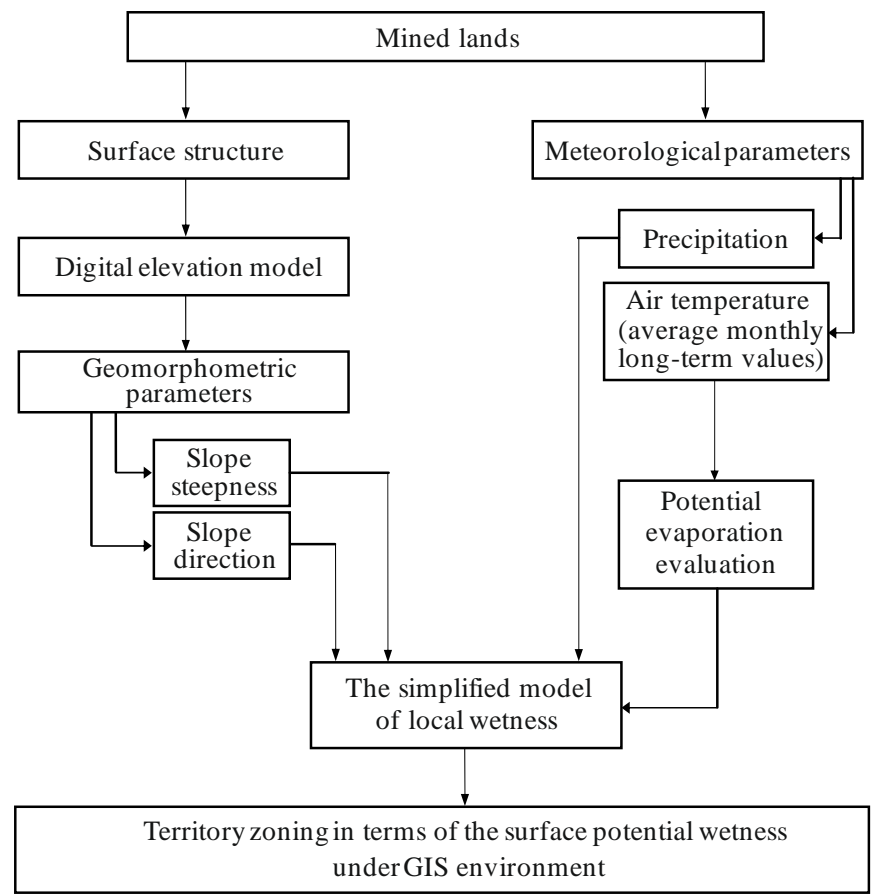

Figure 2. Conceptual approach to determine potential local surface wetness within a mine take involving surface structure of the disturbed land with the use of GIS

Slope steepness and slope direction are the key morphometric terrain characteristics. Slope steepness is an angle between a horizontal plane and slope surface; generally, it is measured in degrees. A range of possible values varies from 0 up to $90^{\circ}$. The steeper the slope is, the larger the slope angle is. Slope direction is the slope orientation relative to cardinal points. Exposure is measured clockwise in degrees from 0 to $360^{\circ}$. It may be expressed points of the compass (rhumbs) with varying detailing. 
General idea of geoinformation analysis of a surface structure involves carrying-out of morphometric study based upon digital elevation model (DEM). If a raster DEM is applied, then slope direction and steepness may be determined for a random element of the raster model with the use of information of adjacent cells (difference in a cell height and size). As for the central cell, surrounded by a $3 \times 3$ cell, the known Zevenbergen-Thorne method involves data analysis from its four vertical and horizontal adjacent cells [21].

In the context of such an approach, raster data sets are the initial data of morphometric analysis under the GIS environment. Right raster model should become a basis to implement the simplified model of local wetness under GIS.

QGIS tools have provided the development of the methods to identify local wetness conditions within the disturbed lands. QGIS is one of the advanced software applications to create, correct, visualize, and analyze spatial data.

To calculate the geometrization slope index, the raster DEM has been applied to determine slope steepness and direction for the northeast part of the technogenic landscape protected area Vizyrka. The meteorological data, required to calculate $E_{0}$, were selected from a set of the basic average monthly and annual climatic characteristics in terms of a Kryvyi Rih weather station for 1983-2002 period [22].

In the context of empiric dependences (by A.N. Postnikov), 832.7 and $791.8 \mathrm{mmpa} E_{0}$ values were obtained for the analyzed territory. The known potential evaporation index for Kryvbas, being 800 mmpa, [4] matches as close as possible the obtained $E_{0}$ values. 812.3 mmpa value, being average $E_{0}$ index for Kryvbas, has been selected as the background one. Average annual precipitation for Kryvbas is $457 \mathrm{~mm}$ [22].

Geometrization slope index, average annual precipitation as well as average annual evaporation value are the required parameters to identify local wetness conditions. The territory was zoned in terms of threshold values of potential local wetness.

\section{Results and discussion}

Relying upon the data of radiation balance, E.N. Romanova calculated in 1966 potential evaporation changes in terms of the northern and southern slopes, varying in steepness (with 5, 10, 15 and $20^{\circ}$ detailing), for a number of stations, located in different geographical zones relative to the potential evaporation from a horizontal surface [23]. Askaniia Nova station, located in the steppe zone of Ukraine at a $150 \mathrm{~km}$ distance south-southeasterly from the technogenic landscape protected area Vizyrka, turned out to be the closest to Kryvbas.

According to the data by [23], a linear dependence (with 0.998 correlation coefficient $(r)$ ) has been determined between the ratios of potential evaporation within the northern and southern slopes, varying in steepness $\left(E_{\text {slope }}\right)$, to potential evaporation from a horizontal surface $\left(E_{f l a t}\right)$ and the geometrization slope index $\left(k_{s}\right)$ for Askaniia Nova station (Fig. 3).

The dependence supports the idea that in the context of the steppe Ukrainian zone (the northern hemisphere, middle latitudes), geometrization slope index and $E_{\text {slope }} / E_{\text {flat }}$ ratio is more than 1 for the southern slopes and less than 1 for the northern ones.

Hence, in terms of the obtained linear dependence, extra correction $k_{s}$ will improve zoning reliability of the surface, disturbed by mining in terms of the available classification of humidification of geographical areas.

Figure 4 represents visually practical implementation of the proposed methodological approach to identify local wetness conditions with the use of GIS.

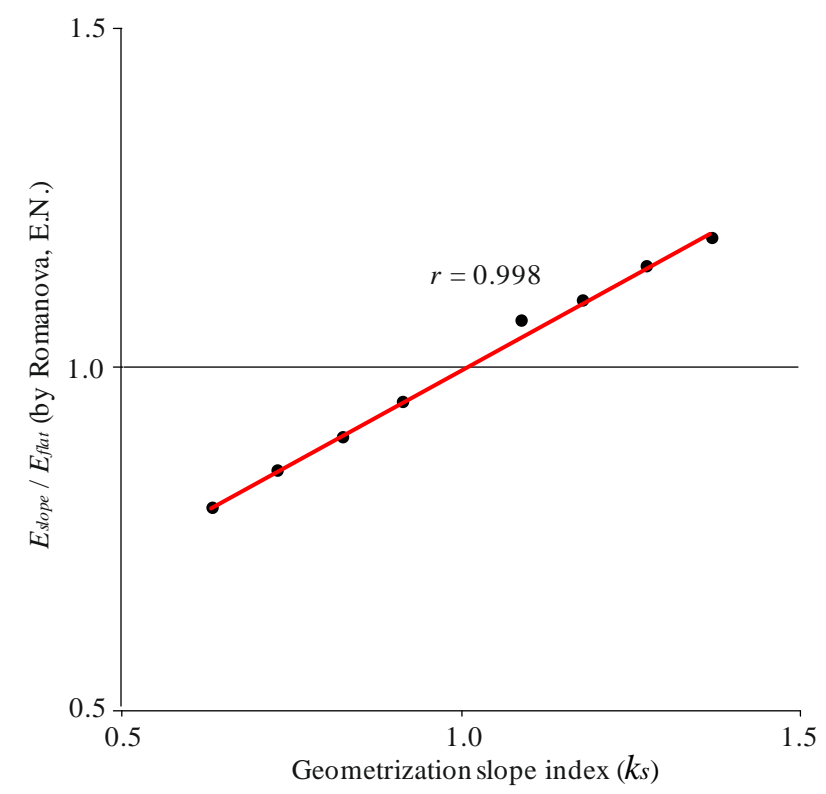

Figure 3. Graphical representation of a dependence between $E_{\text {slope- }} E_{\text {flat }}$ ratio (by E.N. Romanova) and the geometrization slope index (a)

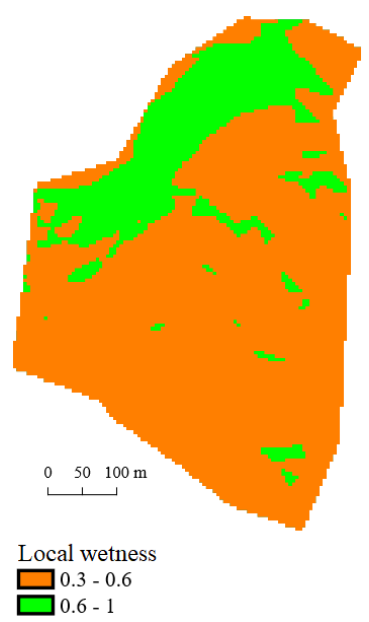

(b)

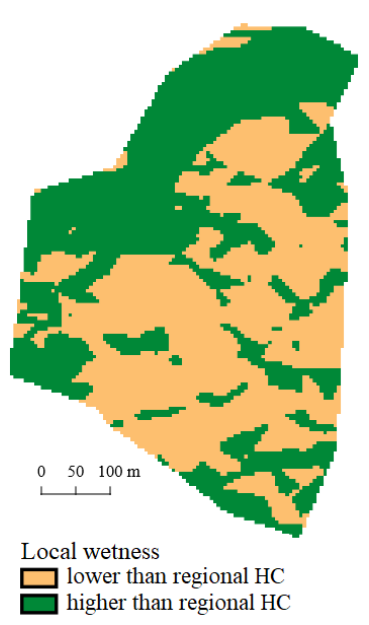

Figure 4. Cartographic model of potential local wetness of the territory with the consideration of the disturbed land structure (the northeast part of the technogenic landscape protected area Vizyrka): (a) is zoning in terms of the classification of humidification of geographical areas; (b) is zoning in terms of a background value

The approach application has helped determine differences in the potential surface wetness in the northeast part of the technogenic landscape protected area Vizyrka is 0.54-1.65 times more to compare with the regional humidity coefficient.

The territory zoning according to local wetness conditions is the final result of the substantiated selection of land areas disturbed by mining to introduce plants. In terms of humidification classification of geographical areas (by F.N. Mil'kov), 0.6-1.0 humidification corresponds to forest- 
steppe conditions; and 0.3-0.6 humidification corresponds to steppe conditions. Consequently, typical representatives of forest-steppe and steppe flora are potential cultures to be introduced at the disturbed Kryvbas territories.

The simplified model of local wetness, proposed by the authors, takes into consideration only atmospheric precipitation. The model relies upon the potential evaporation index correction through such morphometric terrain characteristics as slope steepness and exposure. The model is reasonable if only a value of a geometrization slope index is positive $\left(k_{s}>0\right)$.

$k_{s} \leq 0$ condition is promising for certain slopes of the northern exposure with $45^{\circ}$ and more steepness; namely, for a slope with $0^{\circ}$ exposure (or $360^{\circ}$ one) and $\geq 45^{\circ}$ steepness; for a slope with $89^{\circ}$ exposure (or $271^{\circ}$ one) and $\approx 89.1^{\circ}$ and more steepness. Hence, the northerly a steep slope is $\left(>45^{\circ}\right)$ the higher likelihood of condition $k_{s} \leq 0$ implementation is. However, specific weight of such areas within Kryvbas (exclusive of open pits) is minor. In such a way, at the territory of the technogenic landscape protected area Vizyrka the index is more or less $0.03 \%$.

Further activities will be intended to:

a) specify parameters for extra $k_{s}$ in terms of other sets of actinometrical or meteorological data (first of all, it concerns the slopes which steepness is $>20^{\circ}$ );

b) improve the local wetness model as for the consideration of other moisture sources (first of all, it concerns runoff);

c) determination of interrelation between SMLW data and the certain parameters of soil and flora condition.

\section{Conclusions}

To substantiate the selection of promising areas of the disturbed Kryvbas land from the viewpoint of plant introduction involving potential wetness of the territory, a concept to apply a local wetness coefficient gained its further development. The proposed approach to identify local wetness conditions involves correction of potential evaporation values taking into consideration a local surface structure. Geometrization slope index, considered as a correcting potential evaporation factor, may be calculated on the basis of the terrain morphometric analysis with GIS use. The index needs further correction in terms of the known values of evaporation from a horizontal surface as well as from the slopes varying in exposure and steepness.

In terms of the available classification of humidification of geographical zones, the surface zoning of areas, disturbed by mining, is the practical implementation of the proposed methodological approach to identify local wetness conditions.

Use of the empiric dependences to calculate potential evaporation from the excessively moisture surface as well as from water body (by A.N. Postnikov) for Kryvbas conditions has provided the results, approaching the reference data.

\section{Acknowledgements}

The research has been carried out as a part of the scientific project "Forming secondary ecosystems as the way to recover a diversity of landscape and biotic diversity of the disturbed land" (the state registration number is 0115U001313) of the Target Complex Research Interdisciplinary Programme of the National Academy of Sciences of Ukraine to develop scientific foundations for rational use of natural and resource potential and sustainable development.

\section{References}

[1] Beresnevich, P.V., \& Den'gub, V.I. (2000). Otsenka zagryazneniya atmosfery pyl'yu kar'erov i otvalov. Gornyy InformatsionnoAnaliticheskiy Byulleten', (7), 78-80.

[2] Shapar', A.G. (2005). Ecological problems of the mining industry and some ways of their solution. Gornyy Zhurnal, (5), 20-23.

[3] Marshall, J.K. (1973). Drought, land use and soil erosion. In The Environmental, Economic and Social Consequences of Drought (pp. 55-77). J.V. Lovett (Ed.). Sydney, Australia: Angus and Robertson.

[4] Kazakov, V.L., Paranko, I.S., Smetana, M.H., Shypunova, V.O., Kotsiuruba, V.V., \& Kalinichenko, O.O. (2005). Pryrodnycha heohrafiia Kryvbasu. Kryvyi Rih, Ukraina: Kryvorizkyi Natsionalnyi Universytet.

[5] Postnikov, A.N. (2004). Formuly dlya rascheta srednego godovogo ispareniya s poverkhnosti sushi i radiatsionnogo balansa uvlazhnennoy poverkhnosti. Problemy Sovremennoy Gidrologii, 143-153.

[6] Kondrat'ev, K.Ya., Pivovarova, Z.I., \& Fedorova, M.P. (1978). Radiatsionnyy rezhim naklonnyh poverhnostey. Leningrad, Rossiya: Gidrometeoizdat.

[7] Tian, Y.Q., Davies-Colley, R.J., Gong, P., \& Thorrold, B.W. (2001). Estimating solar radiation on slopes of arbitrary aspect. Agricultural and Forest Meteorology, 109(1), 67-74. https://doi.org/10.1016/s01681923(01)00245-3

[8] Travleev, L.P. (1976). O lokal'nyh koeffitsientah uvlazhneniya edafotopov v lesnyh biogeotsenozah stepnoy Ukrainy. Voprosy Stepnogo Lesovedeniya i Okhrany Prirody, (6), 37-43.

[9] Skrypnyk, O.O. (1995). Ekolohichni osoblyvosti nakopychennia khloru $v$ bioheohoryzontakh chornozemnykh hruntiv spravzhnikh stepiv Ukrainy. Dnipropetrovsk, Ukraina: Dnipropetrovskyi derzhavnyi universytet.

[10] Skrypnyk, O.A. (2019). Kolichestvennaya otsenka lokal'nykh usloviy uvlazhneniya sklona s ispol'zovaniem geometrizacionnykh parametrov poverkhnosti. In Ekolohichni Problemy Navkolyshnoho Seredovyshcha ta Ratsionalnoho Pryrodokorystuvannia v Konteksti Staloho Rozvytku (pp. 68-69). Poltava, Ukraina.

[11] Kolomyc, Ye.G. (2010). Lokal'nye koeffitsienty uvlazhneniya i ikh znachenie dlya ekologicheskikh prognozov. Izvestiya RAN. Seriya Geograficheskaya, (5), 61-72.

[12] Beven, K.J., \& Kirkby, M.J. (1979). A physically based, variable contributing area model of basin hydrology. Hydrological Sciences Bulletin, 24(1), 43-69. https://doi.org/10.1080/02626667909491834

[13] Quinn, P.F., Beven, K.J., \& Lamb, R. (1995). The $\ln (a / \tan \beta)$ index: How to calculate it and how to use it within the TOPMODEL framework. $\mathrm{Hy}$ $\begin{array}{llll}\text { drological } & \text { Processes, } & 9(2), & 161-182 .\end{array}$ https://doi.org/10.1002/hyp.3360090204

[14] Tarboton, D.G. (1997). A new method for the determination of flow directions and upslope areas in grid digital elevation models. Water Resources Research, 33(2), 309-319. https://doi.org/10.1029/96wr03137

[15] Sørensen, R., Zinko, U., \& Seibert, J. (2006). On the calculation of the topographic wetness index: evaluation of different methods based on field observations. Hydrology and Earth System Sciences, 10(1), 101-112. https://doi.org/10.5194/hess-10-101-2006

[16] Troshkina, G.N. (2006). Matematicheskoe modelirovanie protsessov teploobmena $v$ sisteme "solnechnyy kollektor - akkumulyator tepla". Barnaul, Rossiya: Altayskiy Gosudarstvennyy Universitet.

[17] Skrypnyk, O.O. (2016). Upravlinnia ekolohichnoiu bezpekoiu porushenykh hirnychymy robotamy zemel $z$ vykorystanniam heometryzatsiinykh parametriv poverkhni. Kyiv, Ukraina: Derzhavna Ekolohichna Akademiia Pisliadyplomnoi Osvity ta Upravlinnia.

[18] Keating, K.A., Gogan, P.J.P., Vore, J.M., \& Irby, L.R. (2007). A simple solar radiation index for wildlife habitat studies. Journal of Wildlife Management, 71(4), 1344-1348. https://doi.org/10.2193/2006-359

[19] Postnikov, A.N. (2010). Priblizhennyy metod otsenki ispareniya s ozer i vodokhranilishh. Uchenye Zapiski Rossiyskogo Gosudarstvennogo Gidrometeorologicheskogo Universiteta, (13), 21-29.

[20] Mil'kov, F.N. (1977). Prirodnye zony SSSR. Moskva, Rossiya: Mysl'.

[21] Zevenbergen, L.W., \& Thorne, C.R. (1987). Quantitative analysis of land surface topography. Earth Surface Processes and Landforms, 12(1), 47-56. https://doi.org/10.1002/esp.3290120107

[22] Bahrii, I.D., Hozhyk, P.F., Samotkal, E.V., Shestopalov, V.M., Aksom, S.D., Antonov, O.M., \& Shchulipenko, T.F. (2005). Hidroekosystema Kryvorizkoho baseinu - stan i napriamky polipshennia. Kyiv, Ukraina: Feniks.

[23] Romanova, E.N. (1966). Otsenka uvlazhnennosti pologikh sklonov v teploe vremya goda na Evropeyskoy territorii SSSR. Trudy GGO, (190), 19-31. 


\section{Визначення локальних умов зволоження на порушених гірничими роботами землях із використанням ГІС}

\section{О. Скрипник, А. Шапар, О. Тараненко}

Мета. Методичне забезпечення визначення локальних умов зволоження на порушених гірничими роботами землях Кривбасу із врахуванням будови поверхні з використанням геоінформаційних технологій. Саме будова поверхні $є$ визначальним фактором, який впливає на відмінності у зволоженні грунту на локальному рівні.

Методика. Спрощена модель локального зволоження, що була запропонована, спирається на коригування значення випаровуваності із поправкою на рельєф та врахуванні в якості джерела надходження вологи тільки атмосферних опадів. Використання методів просторового аналізу в геоінформаційних системах (ГІС) забезпечить виявлення відмінностей у будові поверхні порушених земель та відповідне коригування значень випаровуваності.

Результати. Виявлено лінійну залежність між відношенням випаровуваності на північних та південних схилах різної стрімкості до випаровуваності з горизонтальної поверхні (за О.Н. Романовою) та геометризаційним індексом схилу для степової зони України. Також на основі спрощеної моделі локального зволоження було уточнено регіональний коефіцієнт зволоження для локальних умов в 0.54-1.65 рази в межах північно-східної частини техногенного ландшафтного заказника "Візирка".

Наукова новизна. Врахування складності будови поверхні через стрімкість та експозицію схилів забезпечує коригування значень випаровуваності та відповідного кількісного визначення локальних умов зволоження на порушених землях із використанням ГІС. Встановлено, що геометризаційний індекс схилу потребує додаткового коригування за відомими значеннями випаровуваності зі схилів різної експозиції та нахилу.

Практична значимість. Запропонований підхід дозволяє виконати зонування території гірничого відводу за потенційним локальним зволоженням поверхні в середовищі ГІС, що забезпечує обгрунтований вибір перспективних ділянок для інтродукції рослин на порушених землях.

Ключові слова: локальне зволоження, геометризаційний індекс схилу, порушені гірничими роботами землі, стрімкість схилу, експозиція схилу, ГІС

\section{Определение локальных условий увлажнения на нарушенных горными работами землях с использованием ГИС}

\section{О. Скрипник, А. Шапарь, О. Тараненко}

Цель. Методическое обеспечение определения локальных условий увлажнения на нарушенных горными работами землях Кривбасса с учетом строения поверхности с использованием геоинформационных технологий. Именно строение поверхности является определяющим фактором, который влияет на отличия в увлажнении почвы на локальном уровне.

Методика. Упрощенная модель локального увлажнения, которая была предложена, основывается на корректировке значения испаряемости с поправкой на рельеф и учете в качестве источника поступления влаги только атмосферных осадков. Использование методов пространственного анализа в геоинформационных системах (ГИС) обеспечит выявление отличий в строении поверхности нарушенных земель и корректировку значений испаряемости соответственно.

Результаты. Выявлено линейную зависимость между отношением испаряемости на северных и южных склонах разной крутизны к испаряемости с горизонтальной поверхности (по Е.Н. Романовой) и геометризационным индексом склона для степной зоны Украины. Также на основе упрощенной модели локального увлажнения был уточнен региональный коэффициент увлажнения для локальных условий в 0.54-1.65 раза в пределах северо-восточной части техногенного ландшафтного заказника "Визирка".

Научная новизна. Учет сложности строения поверхности через крутизну и экспозицию склонов обеспечивает корректировку значений испаряемости и соответствующего количественного определения локальных условий увлажнения на нарушенных землях с использованием ГИС. Установлено, что геометризационный индекс склона требует дополнительной корректировки по известным значениям испаряемости со склонов разной экспозиции и наклона.

Практическая значимость. Предлагаемый подход позволяет выполнить зонирование территории горного отвода по потенциальному локальному увлажнению поверхности в среде ГИС, что обеспечивает обоснованный выбор перспективных участков для интродукции растений на нарушенных землях.

Ключевые слова: локальное увлажнение, геометризационный индекс склона, нарушенные горными работами земли, крутизна склона, экспозиция склона, ГИС

\section{Article info}

Received: 27 February 2020

Accepted: 6 November 2020

Available online: 7 December 2020 